\title{
Capital Structure, Cash Holdings and Firm Value: a Study of Brazilian Listed Firms
}

Tiago Rodrigues Loncan

M.Sc. in Business Management, Federal University of Rio Grande do Sul, Student, Laurea Magistrale in Economics, University of Bologna

E-mail: tiago.loncan@gmail.com

\section{João Frois Caldeira}

Adjunct Professor, Department of Economics and Graduate School of Management. Postgraduate Program in Management, Federal University of Rio Grande do Sul E-mail: joao.caldeira@ufrgs.br

Received on 3.31.2013 - Desk acceptance on 3.31.2013 - $3^{\text {rd }}$ version approved on 2.12.2014

\section{ABSTRACT}

This study analyzed the relationship among capital structure, cash holdings and firm value for a sample of publicly traded Brazilian firms, through panel data regressions, employing the fixed-effects estimator. Initially, it was estimated regressions between capital structure (debt to total capital) and cash holdings (cash to assets), as well as between cash holdings and short and long-term debt. Next, it was applied a regression among firm value, capital structure and cash holdings. The results of this study suggested that debt, both short and long-termed, is negatively related to cash holdings, and that the level of cash holdings is also associated to a lower leverage. The study also presented indirect evidence that financially constrained firms hold more cash. Regarding to the impact of the capital structure on the firm value, short-term debt, long-term debt and the financial constraint had negative marginal effects on the firm value, suggesting a risk-averse behavior of investors in relation to debt. Cash holdings, instead, is valued as positive by investors, but up to an optimum threshold level. Further, the market capitalization is discounted with respect to cash holdings (inverted U-curve), in synergy with static trade-off theory of cash holdings.

Keywords: Capital structure. Cash holdings. Firm value. 


\section{INTRODUCTION}

In a so called "perfect market economy", in which there are no frictions, transaction costs and taxes, the way firms' investments are financed would be irrelevant for the firm value, as proposed by Modigliani and Miller (1958). However, it is clear that financial markets cannot be defined in such ways. As argued by Portal, Zani, and da Silva (2012), frictions and transaction costs are indeed real constraints that firms must face when choosing their financing strategy. Considering this setup of frictions, transaction costs and asymmetry of information in debt markets, and also building on Harris and Raviv (1991), the choice between debt and equity financing, and the resulting level of leverage might affect firm value.

Sunder and Myers (1999) argue that among the many theoretical frameworks proposed to evaluate the rational and consequences of capital structure choices, two theories are the most prominent: the static trade-off theory and the pecking order theory. The static tradeoff theory argues that there is a target level of debt-toequity ratio, in which the present value of tax-shields (tax benefits) would equal the financial distress cost (bankruptcy risk), point in which firm value would be maximized (Sunder \& Myers, 1999). The Pecking Order Theory, instead, proposes that the level of debt of a given firm does not follow a target, but just an order of preference of financing options determined by availability and cost of resources. Firms would contract debt when they cannot balance their resource requirements for financing new projects with their internal cash generation (Myers, 1984).

Regarding cash holdings, a similar discussion was proposed in former research. The static trade-off model of liquid assets, by Miller and Orr (1966), predicts that firms balance the main cost of holding cash, which is the opportunity cost of holding no interest-bearing money, versus the main benefit of holding cash which is to guarantee funding for future investments in the event of a cash flow shortage. Optimum cash would be set when marginal cost and benefit intercept. It follows from the existence of an optimum value for cash holdings that the cash policy can impact firm value. On the other hand, a Pecking Order of cash holdings should yield similar predictions as for leverage: no target level of optimum cash, as cash would be used as a buffer between retained earnings and investment needs (Ferreira \& Vilela, 2004).

Other stream of literature considers cash just as negative debt. As argued by Acharya, Almeida, and Campello (2007), the view that cash is negative debt would hold only if financial markets were frictionless. If there are contracting costs and costs arising from asymmetry of information, as argued by authors, these costs should influence the financing policy of firms, and cash holdings would have indeed an economic value, not being only the reverse of debt. Cash holdings would play an important role especially for financially constrained firms, as they face higher costs to access external financing. Moreover, many past studies documented a negative relationship between leverage and cash holdings (Ferreira \& Vilela, 2004; Opler, Pinkowitz, Stulz, \& Williamson, 1999; Bigelli \& Sanchez-Vidal, 2012; D’Mello, Krishnaswami, \& Larkin, 2008).

The Brazilian setup is an interesting environment to study the problem. Because due to long dated economic policies, the cost of capital is much higher than in more developed countries and many firms suffer from credit constraints (Terra, 2003). Also, the debt market in Brazil is less mature when contrasted to US or European markets, with less transactions and lower liquidity (Sheng \& Saito, 2008). Other interesting feature is that because emerging economies, including Brazil, tend to have higher interest rates when compared to more developed economies (Neumeyer \& Perri, 2005), the opportunity cost of holding cash is higher. Hence, a study combining the financial leverage and cash holdings policies can yield interesting insights about how these variables behave in a financial market that can be restrictive, in which firms can run short of cheap capital to finance their investments.

Moreover, in a financial market characterized as such, it is interesting to assess how financing and cash policies can affect firm value. Because of high costs, is debt perceived as negative by investors, and, if it is affirmative, does the maturity of debt (short or longterm) influence firm value differently? Considering a high opportunity cost of holding cash coupled with the possibility of facing restrictions to finance future investments due to financing cost escalation, how is the cash holdings position of a firm priced by investors in terms of impact on firm value?

The study had three main objectives. First, we studied the capital structure decision of Brazilian firms, with special interest in the relationship between leverage and cash holdings. Next, we analyzed the determinants of cash policies, with marked interest on the impact of short and long-term leverage, but controlling for other important variables. Finally, we evaluated the impact of capital structure and cash holdings policy on the firm value, also controlling for other relevant variables. This paper brings interesting contributions: First, we combine capital structure and cash holdings approaches in a single study and try to improve knowledge on how these variables relate. Many papers studied capital structure and cash holdings separately, but fewer studies conciliated these important topics in a single study, especially in Brazil. Thus we seek to bridge this gap. Second, we evaluate how capital structure and cash holdings policy affect firm value in the Brazilian economic environment, which has peculiar 
and important financial characteristics that differ from other economies that have more mature and developed financial markets. There were many former studies documenting theoretical rationales for both capital structure and cash policies to affect firm value, but not so many papers addressed the problem empirically, and even fewer (if any) evaluated how capital structure and cash holdings affect firm value in a single study, leaving room for further investigation. We tackle this problem in our study, hence presenting contributive insights.

\section{LITERATURE REVIEW}

\subsection{Capital Structure.}

Many former studies aimed to establish determinant factors of capital structure. Although, depending on the departing theory, different assumptions can be made about the relationship between variables and capital structure levels, some general patterns have been identified (Smart, Megginson, \& Gitman, 2007). We shortly review some of the most important determinants.

Leverage has an important within-industry pattern, which means, firms usually choose capital structure in ways that it would converge to the average of the industry (Hovakimian, Opler, \& Titman, 2001). Larger firms usually rely more on debt, as the firm size itself is trustworthy collateral for guaranteeing the service of debt or the payment of the residual cash in case of liquidation (Rajan \& Zingales, 1995).

Growing firms normally present growing cash flows too, so debt financing is usually replaced by internal funding. Also, growing firms are riskier, so the financial distress cost should be higher, hence implying less debt (Frank \& Goyal, 2009). In the same direction, Perobelli and Fama (2003) argue that growing firms are more prone to rely on the equity market to finance new projects. In the same line, Kayo and Famá (1997) found that leverage is lower for growing firms for a sample of Brazilian companies.

The more profitable the firm is, the less debt it tends to employ (Kayhan \& Titman, 2007). The same result was reported by Futema, Basso, and Kayo (2009), analyzing Brazilian public companies. Since profitable firms can accumulate profits, they may use retained earnings to finance new investments, using debt only after running short of internal resources. A similar reasoning may apply to cash flows. As argued by Jensen (1986), firms that generate more cash flows can use these resources to redeem debt, and by having high cash flows, managers don't need external financing (Ferreira \& Vilela, 2004). Hence, leverage is likely to be decreasing on cash flows.

As argued by Ferreira and Vilela (2004), the relationship of cash holdings with leverage can have two possible forms. First, because more levered firms want to reduce the risk of financial distress, as the cost of amortization plans of debt is likely to put a burden on firm's treasury, they could hold high quantities of cash. On the other hand, because the leverage ratio is a proxy for the credit status of a firm or its ability to issue debt, higher leverage can be associated to lower cash holdings. However, as suggested by D'Mello, Krishnaswami, and Larkin (2008), cash holdings could be endogenous to leverage. The argument is that, as the determinants of cash are so closely related to the determinants of leverage, it is interesting to assess whether they are two sides of the same coin, similar to the discussion developed by Acharya et al. (2007) that suggested that cash could be negative debt.

Following the static-trade off approach, as argued by Sunder and Myers (1999), escalated costs of debt should lead to a situation in which the cost of debt is so high that firms can't keep increasing borrowing. Also following Pecking order, if the cost of debt becomes too high, it may overcome even the cost of other sources of funds, like equity. Hence, increasing costs of debt should lead to a reduction or at least saturation point of leverage.

One last important determinant of debt that we approach in the review is the role of stock market liquidity. It is because firms' stocks that show high trading volume allow these firms to rely more on the equity market for financing, high liquidity usually affects capital structure by reducing the level of leverage (Lipson \& Mortal, 2009; Morellec, 2001). One other result that relates stock market activity with leverage is the one reported by Dimitrov and Jain (2008), in which growing debt is associated to negative stock market returns.

Under an Agency-Theory perspective, the decision on which source of financing will be chosen by firms reflects conflicts among managers, equity holders and debt holders. Contracting debt implies that the firm will have to face the cost of this option by doing cash payments in the future, in such ways that managers would have less cash available to spend in general expenses. Debt financing could be a way equity holders could monitor and constraint manager's expending behavior (Jensen, 1986).

Agency conflicts between equity holders and debt holders can emerge from opportunistic behavior, principally from equity holders. As argued by Harris and Raviv (1991), the debt financing allows for the possibility that the investment to be financed with such debt may yield higher returns than the face value of debt, thus equity holders may have an incentive to invest in riskier projects, as they capture the differential gains. If the riskier projects are successful, equity holders are better off, whereas if these projects fail, costs are borne by debt holders, conflict known as "asset substitution problem". However, if debt holders anticipate the future behavior of equity holders, the costs of investing in riskier projects will be borne by equity holders, whereas the cost of debt already incorporates the higher risk by having a higher cost (spread). 
Under the agency-theory approach, optimal capital structure would be obtained by balancing the agency costs and the agency benefits of debt among all cash claimants (Leland, 1998). As the financing by debt would be a way to balance power and expectations among all cash streams claimants, the final impact of leverage into firm value is considered to be positive (Harris \& Raviv, 1991).

Bradley, Jarrel, and Kim (1984) argue that, instead, optimal capital structure is a function of the trade-off between the tax benefits of debt and the associated costs (risks) of bankruptcy. Firms would reach optimality of capital structure precisely by balancing the benefits and costs of financing options (Bancel \& Mitto, 2004). That is the main postulate of the Static Trade-off Theory of capital structure.

For Sunder and Myers (1999), the static model is based on the existence of an optimality point between the present value of the benefits of tax shields and the present value of costs of financial distress, being the firm value maximized when these two elements equate on their margins. Tax benefits arise because firms can deduct the interest cost of debt from the taxable profits, booking the paid interest as a financial expense (Procianoy \& Schmitt, 1995). On the other hand, the marginal cost of financial distress is a growing function of the debt level, so the more levered the firm is, higher is the probability of bankruptcy (Smart et al., 2007). Once firms have identified this point of optimality, they would target the resulting capital structure level. So the decisions of issuing more debt or switching for internally funding over time would reflect this chase of an equilibrium point of debt-to-equity ratio in which firm value is maximized.

The concept of asymmetry of information is the underpinning for other two important capital structure theories. Ross (1977) proposed a model in which managers may use the proportion of debt to signal to stock market investors that the future prospects of the firm are actually better than what is incorporated in the stock prices. Since managers are insiders and hence are better informed, they will be more accurately to assess than outside investors what are the future earnings streams for the company.

Issuing more debt would be a signal of the high quality of the future cash flows, and assuming that only high-quality firms would bear the risk of issuing debt (that means, this signal could not be falsely imitated by lowquality firms), managers would opt for financing new projects with debt to signal good future prospects, being compensated by superior performance and penalized by growing bankruptcy risks. This model is known exactly as the Signaling Theory of capital structure, and predicts that, given the fact that debt signals good news about the firm, more levered firms would exhibit better stock market performance (Harris \& Raviv, 1991). On the other hand, Dimitrov and Jain (2008) reported that growing debt is associated to negative stock market returns, contradicting the expected results of signaling theory.
The Pecking Order theory, differently from the other theories we discussed so far, departs from another concept. Myers and Majluf (1984) suggest that if inside managers are better informed then outside investors about the current value of the firm's equity, it implies that equity may be mispriced by the stock market.

Hence, financing new projects by issuing new equity would make underpricing even more severe, and the new investors who acquired the recently issued shares would capture value at the expenses of prior shareholders. Under these conditions, managers would forego even projects with positive net preset value, preventing value destruction for current shareholders. Firm then would go through an underinvestment process. The way to solve this underinvestment problem would be to finance new ventures using a security that is not so undervalued (Harris \& Raviv, 1991). Internally generated resources and debt (at acceptable risk levels) are sources of funds that do not involve undervaluation.

For Sunder and Myers (1999), the choice among internal cash flows, debt and equity as financing option is done considering the cost of funds. The less costly funds would be internal cash, followed by (moderatedrisky) debt, and finally, equity would be issued as a last option. Pecking Order theory advocates that leveraging is a way to reply for a punctual demand for funds, normally when the internal cash flows are not enough to finance new investment opportunities, simply a costbenefit decision.

\subsection{Cash Holdings.}

Opler, Pinkowitz, Stulz, and Williamson (1999) argue that managers that maximize shareholder value would set the firm's cash level such that the marginal benefits of cash equals the marginal costs of holding these assets. The benefits of holding cash are mainly that the firm saves transaction costs when raising funds, also avoiding liquidating assets to make payments, and further because firm has independency to finance investments with these liquid assets, not being harmed when other sources are not available. The main cost of holding cash arises from the liquidity premium discount, also defined as the opportunity cost of holding cash. Clearly, this is a static trade-off approach.

On the other hand, under a pecking order theory assumption, firms would not have target cash levels. Instead, cash is used as buffer between retained earnings and investment needs. Basically, when retained earnings are not enough to finance new investments, firms use cash holdings to do so, and in the last circumstance, they issue debt (Ferreira \& Vilela, 2004). Furthermore, there is a fixed cost of accessing external funding, so firms raise external capital infrequently, therefore relying more often on cash holdings to finance projects (Opler et al., 1999).

Departing from an agency-theory approach, cash holdings are kept high by entrenched managers, because they prefer to hold cash than to payout more dividends to shareholders (Bates, Kahle, \& Stulz, 2009). 
Furthermore, by holding more cash, managers increase the amount of assets under their control and gain more power over the firm investment decision. Managers also would escape from raising capital externally, which in turns allows them to not disclose information about investment projects to the outside investor market (Ferreira \& Vilela, 2004).

Bates, Kahle, and Stulz (2009) point out four basic reasons why firms would hold cash. The first reason would be the transaction costs motive, in the sense that firms hold cash to avoid incurring in the costs of converting a non-financial cash asset into a more liquid asset, to have resources to meet payments due. The second reason is called the precautionary motive, as firms hold cash to better cope to adverse shocks when external financing is costly.

The third reason is about taxes, because by holding more cash firms can mitigate tax burdens of repatriating profits from foreign operations (this reason is closely linked to multinational firms). Finally, the fourth reason would be agency implications, as we discussed before, because entrenched managers tend to build more excess cash balances.

One first determinant of cash holdings would be the magnitude of the costs to access external funding. Firms with facilitated access to capital markets and good credit rating from rating agencies should have lower transaction costs when accessing debt markets, so they are expected to hold less cash. On the other hand, following Acharya et al. (2007), financially constrained firms, which can be firms with less easy access to capital markets or firms that are already paying a very high cost of debt due to escalated risk of existing outstanding debt, seeking to avoid to be short of funds to finance investments, would hold more cash.

In a similar fashion, firms facing high investment opportunities are likely to hold more cash, because the cost of being short of cash is letting these projects go away (Han \& Qiu, 2007). So to possess the required resources for investing in positive NPV projects, firms would hold excess cash. Also, the type of investments may matter, as firms investing more in $\mathrm{R} \& \mathrm{D}$ and expending more in advertising, sales expenses and other discretionary outflows are likely to hold more cash, because the cost of financial distress for these firms is higher, due to a higher proportion of intangible assets in comparison to hard assets (Opler et al., 1999). Con- versely, higher asset tangibility is associated to lower cash holdings (John, 1993).

Another determinant of cash holdings strictly linked to cash availability is the uncertainty of cash flows. Higher uncertainty of cash flows, or risk, should imply more cash holdings (Ozkan \& Ozkan, 2004), as uncertainty leads to more situations in which the firm has more outlays then expected.

For firm size, Ferreira and Vilela (2004) argue that depending on the theory approach the expected cash holdings may be opposite. Under a static trade-off assumption, there are economies of scale in cash management; so bigger firms would hold less cash then smaller ones, also because recurring to external funding is usually less costly for large firms. However, under a pecking order analysis, larger firms are prone to be more successful, and hence should hold more cash, after controlling for investment.

Mikkelson and Partch (2003) discuss whether large cash holdings can hinder operating performance, in the sense that large cash reserves could induce managers to deploy assets in a less efficient way, because there is too much cash available to spend. They find that, actually, higher cash reserves are associated to higher operating performance.

Prior studies on US public companies showed that firms commit themselves to regular payment of dividends, to reduce managerial agency costs, as firms must regularly come back to equity market to raise new funds to finance investments. Thus, firms do not adjust their payout policy due to performance very frequently, and the expected result between cash holdings and dividends payment is a negative relationship (Bigelli \& Sanchez-Vidal, 2012).

Finally, more levered firms are expected to hold less cash, as debt grows when investment exceeds retained earnings and falls when investment is less than retained earnings. Cash holdings follow the inverse tendency, falling when investment needs exceeds retained earnings and growing when the opposite takes place. However, as pointed by Portal, Zani, and da Silva (2012) and Acharya et al. (2007), when firms are subject to high external financing costs (constrained fir$\mathrm{ms}$ ), internal and external funds are more complementary than substitute forms of financing, so the inverted relation between cash holdings and leverage may not prevail, as cash holdings and cash flows are positively related (a similar discussion to the difficulty to access external financing we did previously).

\section{METHODS}

\subsection{Sampling and Data.}

Our sample consists of all non-financial firms listed in the Brazilian stock market (BOVESPA - São Paulo Stock Exchange), in the period between 2002 and 2012. The sample includes firms from all non-financial sectors of the economy, and hence we consider it as a good representation of Brazilian business environment. We collected yearly observations for each firm, in a panel that spans from 10 years, which allows capturing a whole decade of business activity. We did not restrict firms in the sample to contemporaneous listing, to maximize the heterogeneity of the sample. As a result, the panel is unbalanced, as many firms went public exactly during the period covered by the sample, so we don't have the same quantity of observations for all firms sampled.

Data was collected from Economatica Investment 
Tool. We removed outliers that presented inconsistent financial ratios which let us understood that could be caused by imprecise figures in the database (like explosive financial ratios), and we also eliminated observations which let us understood that would not fit a study of capital structure, like firms reporting negative equity due to accumulated losses. For the variables that we managed to build the largest panel possible, we run models with up to 2.038 observations concerning 288 different firms during 2002-2012 (having some firms presented missing variables in some years). When including some controlling variables that were not available in the database of Economatica for some firms, or for some years, models had reduced numbers of observations, but no less than 1.101 observations for 209 different firms. Hence, we considered that for both the largest and the smallest panels we used to estimate the regression models, the sample was comprehensive and heterogenic enough.

\subsection{Empirical Models.}

In this section we present the regression models we estimated. Following Wooldridge (2004) and Gujarati (2006), we employed panel data regressions using the Fixed Effects estimator, generally defined as:

$Y_{i t}=\alpha_{i}+\beta_{1} X_{i t}+\ldots+\beta_{2} W_{i t}+\varepsilon_{i t}$

$\mathrm{Y}$ is the dependent variable for firm $\mathrm{i}$ in time $\mathrm{t}$; alpha is the firm-varying linear coefficient (constant); betas are the angular coefficients;

$\mathrm{X}$ and $\mathrm{W}$ are independent (explanatory) variables; epsilon is the residual.

To ensure that the models were estimated respecting the main assumptions of the linear regression's model, we conducted appropriated tests. To prevent problems with heteroskedasticity, we used heteroskedastic robust standard errors. To test for serial autocorrelation of residuals, we used the Durbin Watson statistic. Finally, we checked for possible cases of multicollinearity among regressors by analyzing the correlation coefficient among them, making sure there were no strong correlations that could signal multicollinearity.

The first model relates capital structure to cash holdings, also controlling for important variables. Model 1 is presented below:

$$
\begin{aligned}
D / \mathrm{CaP}_{i t} & =\alpha_{i}+\beta_{1} C / T A_{i t}+\beta_{2} \ln T A_{i t}+\beta_{3} R_{\text {ROIC }}+\beta_{i t} E B / T A_{i t} \\
& +\beta_{5} \text { NetCapex }_{T} T A_{i t}+\beta_{6} F E / E B_{i t}+\beta_{7} F E / E B_{i t}^{2} \\
& +\beta_{8} L i q_{i t}+\varepsilon_{i t}
\end{aligned}
$$

D/Cap is Debt to Capital, defined as the book value of total debt divided by the book value of equity plus the book value of total debt;

$\mathrm{C} / \mathrm{TA}$ is cash holdings, defined as cash divided by the total book value of assets;

$\operatorname{lnTA}$ is the log of Total Assets;
ROIC is the Return on Invested Capital;

$\mathrm{EB} / \mathrm{TA}$ is the ratio of gross cash flows (EBITDA) divided by Total Assets;

NetCapex/TA is Capital Expenditures net of depreciation divided by Total Assets;

FE/EB is Financial Expenses divided by EBITDA, linear and quadratic forms;

Liq is the liquidity ratio, calculated by dividing the stock's trading volume in $\mathrm{R} \$$ millions by the Market Value of Equity in R \$ Millions;

Epsilon is the residual.

Debt to Capital is the dependent variable of the model, and was defined as previously explained. The main independent variable of interest is Cash Holdings. For controlling purposes we used the natural log of Total Assets (lnAT) for size, Net Capex to Total Assets is a proxy for growth / investment opportunities. Return on Invested Capital (ROIC) is the proxy for profitability. EBITDA over Assets (EB/TA) is a measure for gross cash flow generation capacity. Financial Expenses divided by EBITDA (FE/EB) in its linear and quadratic form control for the effect of escalating costs of debt service on the debt level, and finally the Liquidity (Liq) controls for stocks' traded volume.

The second model relates cash holdings to longterm and short-term debt, controlling for important variables that may impact cash holdings. Model 2 is described next:

$$
\begin{aligned}
C / T A_{i t}= & \alpha_{i}+\beta_{1} s t D / C_{\text {Cap }}+\beta_{2} l t D / \text { Cap }_{i t}+\beta_{3} \text { sqrtMVE }_{i t} \\
& +\beta_{4} \text { NetCapex } / T A_{i t}+\beta_{5} P P E / T A_{i t} \\
& +\beta_{6} \text { SGA } / \text { NOR R }_{i t}+\beta_{-} \text {NOR/TA } \\
& +\beta_{8} \text { Beta }_{i t}+\beta_{9} \text { DivYld }_{i t}+\beta_{10} \text { Constr }_{i t}+\varepsilon_{i t}
\end{aligned}
$$

$\mathrm{C} / \mathrm{TA}$ is cash holdings;

stD/Cap is short-term debt to capital';

ltD/Cap is long-term debt to capital';

sqrtMVE is the square root of the market value of equity;

NetCapex/TA is Capital Expenditures net of depreciation divided by Total Assets;

PPE/TA is Property, Plant \& Equipment divided by Total Assets;

SGA/NOR is Selling, General \& Administrative expenses divided by Net Operating Revenue;

NOR/TA is Net Operating Revenue divided by Total Assets, the Assets Turnover;

Beta is the beta coefficient of firm's stock;

DivYld is the dividend yield;

Constr is a dummy for potential financially constrained firms.

In the model exposed above, Cash Holdings is the dependent variable, and Short and Long-term Debt to Capital are the main independent variables. We split debt into short and long-term debt to assess whether the debt maturity can have a different impact on cash holdings, as suggested by Ferreira and Vilela (2004). 
The other variables in the model were used for controlling purposes, to allow for a ceteris paribus effect of debt on cash holdings.

The square root of market value of equity (SqrtMVE) is controlling for size, following Amihud (2002), being included, in accordance with the literature, as smaller firms are likely to hold less cash (Ferreira \& Vilela, 2004; Opler et al., 1999). NetCapex/TA captures the real investment, as investment may affect cash positively, because firms investing more are more likely to better investment opportunities, and thus would hold more cash (Han \& Qiu, 2007). PPE/TA is a proxy for asset tangibility, as firms with a more tangible assets base are likely to keep lower cash balances (John, 1993).

SGA/NOR is a proxy for discretionary expenses, like advertisement and other general and selling expenses, building on insights that firms with more discretionary expenses must hold more cash to cope with these cash outlays (Fresard, 2010). NOR/TA or Asset Turns is a proxy for operating performance / efficiency, following insights of Mikkelson and Partch (2003) that too much cash reserves could affect efficiency negatively. Beta was used to proxy for firm's risk, as riskier firms should hold more cash (Ferreira \& Vilela, 2004), and DivYld is our variable to proxy for firm's payout policy, building on the prediction that dividend payment should be associated to lower cash holdings (Bigelli \& Sanchez-Vidal, 2012).

The variable Constr is a dummy for financially constrained / unconstrained firms. To define if a firm is potentially financially constrained / unconstrained we used a different approach compared to prior studies, and the insight to use it came from ex post our estimation of the model on debt. Anticipating some of the results, we found that Debt to Capital and Financial Expenses over EBITDA ${ }^{3}$ present an inverted U-shaped curve relationship. It means that after the leverage level is associated to a high cost, as a higher fraction of gross cash generated (EBITDA), is necessary to pay the service of debt, the debt level starts to marginally fall. In other words, on average, there is a threshold for the cost of debt that maximizes the leverage level of firms. From that point, leverage falls.

The idea is that growing levels of committed gross cash flows to pay debt would create a situation of financial constraint, because the firm could not contract more $\mathrm{debt}^{4}$. If the firm presented a value for FE/EBITDA on the $75 \%$ percentile of sample, we considered that a high fraction of cash flows was allocated to pay debt service, and the value of 1 was designated for it, being the firm considered potentially constrained. If the value for FE/EBITDA was inferior to the $75 \%$ per- centile, the value designated for the dummy was zero. D'Mello et al. (2008) also used a dummy variable to capture possible capital constraints, but they used a binary rule for rated debt, instead.

To double check for the intuition that we could capture financial constraint by this method, in one of the models developed in the study we regressed the MarketTo-Book ratio against the dummy Constr, among other explanatory variables, to assess if investors would discount the value of financially constrained firms (as defined in our methodology) differently from financially unconstrained firms. We are going to present the output for this regression in the later section of results, but we anticipate that the firms we set as potentially constrained were further discounted in comparison with the ones we set as unconstrained ${ }^{5}$.

The third model explores the relationship among firm value, capital structure and cash holdings, controlling for important variables. Model 3 is presented next:

$$
\begin{aligned}
& M K B_{i t}=\alpha_{i}+\beta_{1} s t D / C a p_{i t}+\beta_{2} l t D / C a p_{i t}+\beta_{3} C / T A_{i t} \\
& +\beta_{4} C / T A_{i t}^{2}+\beta_{5} \text { Constr }_{i t}+\beta_{6}(\text { Constr }) x(s t D)_{i t} \\
& +\beta_{7}(\text { Constr }) x(\text { ltD }){ }_{i t}+\beta_{8} \text { (Constr) } x(C / T A)_{i t} \\
& +\beta_{9} \ln N O R_{i t}+\beta_{10} \text { NetCapex } / T A_{i t} \\
& +\beta_{11} R O I C_{i t}+\beta_{12} L i q_{i t}+\varepsilon_{i t}
\end{aligned}
$$

MKB is the Market to Book ratio (Market value of assets divided by book value of assets);

stD/Cap is short term debt divided by total capital ${ }^{6}$;

ltD/Cap is long term debt divided by total capital ${ }^{7}$;

$\mathrm{C} / \mathrm{TA}$ is cash to assets (cash holdings);

C/TA squared is cash to assets in the quadratic form;

Constr is the dummy for potentially financially constrained / unconstrained firms;

(Constr) $\mathrm{x}(\mathrm{stD}),($ Constr) $\mathrm{x}(\mathrm{ltD})$ and (Constr) $\mathrm{x}(\mathrm{C} / \mathrm{TA})$ are interactions between the dummy Constr and short-term debt, long-term debt and cash holdings;

lnNOR is the natural log of Net Operating Revenue (Size); Net Capex to Total Assets is the variable for investment opportunities;

ROIC is return on invested capital, for profitability; Liq is the liquidity ratio, controlling for stock's liquidity; Epsilon is the residual.

Market-to-Book ratio (MKB) is the dependent variable, Cash Holdings (C/TA), in linear and quadratic forms, Short and Long-term Debt to Capital (ltDebt/Cap; stDebt/Cap) and Financial Constraint (Constr) are the main independent variables. We also control for the impact of Liquidity (Liq), Size (lnNOR), Investment Opportunities (NetCapex/ TA) and Profitability (ROIC) on firm value. We also allowed for interactions between the Constr dummy with Cash Holdings and Short and Long-term Debt.

It is important to discuss our choice to use distinct

${ }^{3}$ Financial Expenses over EBITDA is commonly used as a covenant in debenture issues to signal high levels of risk due to growing debt costs that would trigger an earlier liquidation of the debenture. Usually it is stated as EBITDA / FinExp, but we inverted it to have a ratio, thus facilitating the comparison of the elasticity to the debt-to-capital ratio.

${ }^{4}$ In this approach we are considering that firms are debt-constrained. We did not incorporate any measure of equity constraint, for example.

${ }_{5}^{5}$ Besides, we further correlated the Constr dummy with other three variables that according to past studies would be negatively correlated to financially constrained firms (Acharya et al., 2007; Almeida $G$ Campello, 2007): a) NetCapex/Assets, as a proxy for current investment (Corr=-0.08, p-value <0.01). b) Market-To-Book, as proxy for future investment opportunities (Corr=-0.11, p-value <0.01). c) In Tangible Assets (Total Assets - Liquid Assets): (Corr.=-0.21, p-value <0.01). The negative and statistically significant correlations further suggest that we captured at least partially the financial constraint with our dummy.

${ }^{6}$ Short term debt is the sum of short term loans, financings and debentures divided by total capital, which is total debt plus the book value of equity.

${ }^{7}$ Long term debt is the sum of Long term loans, financings and debentures divided by total capital, which is total debt plus the book value of equity. 
models in the study, instead of employing simultaneous equations. There is theoretical support for a model suggesting that capital structure and cash holdings may affect firm value (mainly the static trade-off theory, as discussed previously). However, to test the converse, that cash holdings and capital structure may be caused by the firm value is a more complicated relationship that has no such strong theoretical support, being not reasonable to assume beforehand that this relationship may hold for the models proposed in this study. Some studies documented that the market value of the firm may serve as collateral for borrowing, causing some endogeneity between firm value and leverage, but it applies to pure financial firms (Adrian \& Shin, 2010). However, our sample does not contemplate this kind of firms.

Furthermore, if the information regarding leverage and cash policy influences firm value, this information conveys relevant news to investors and thus must have a price. If we assume that firm value, leverage and cash holdings are set simultaneously, at the moment investors price a firm's stock they should know what are the relevant figures for cash and leverage, but as these figures are proprietary information of the management of the firm, the best investors can do is to try to guess what these values are, but they don't know for sure, being exactly this the reason why firm value should adjust ex post to information on cash policies and leverage when these are released. Thus, having no theoretical base to suggest reverse causality or simultaneity among firm value, cash holdings and capital structure, neither, prior evidence of endogeneity among the three variables, we preferred to use separate equations.

Former studies suggested a possible endogeneity of leverage in the determination of cash holdings, as cash could be negative debt. However, as argued by Acharya et al. (2007), cash holdings are an important component of firms' optimal financing structure, being correlated to firm value, growth opportunities, risk and performance. Cash policies would be affected by a range of aspects, from access to capital markets to laws protecting minority investors, but literature largely suggests that cash holdings should not be seen as negative debt for a large fraction of firms, as cash would fulfill an important economic role. Moreover, the standard valuation models that give intuition for cash to be just negative debt assume frictionless in financing markets. If we assume that contracting and information frictions entail additional costs to external financing (Acharya, Almeida, \& Campello, 2007), cash holdings will hardly be just negative debt, having an autonomous economic value. Considering the Brazilian financing market case, credit restrictions are very pronounced, especially for small and medium sized firms, building on the argument of Terra (2003). Thus, in a restrictive financing market, we understand that it is more likely that cash holdings indeed play a role, weakening the argument that cash holdings is just the reverse side of debt.

To provide support to this view, we tested for the endogeneity of leverage in the determination model of cash holdings, using the instrumental variables approach, as suggested by Wooldridge (2004). The instrument for leverage we used was the Average Sector Leverage ratio, following D'Mello et al. (2008), as it affects firm choice for leverage, because firms target their industry's leverage ratio when deciding on their own ratio (being a relevant instrument), but it does not affect the cash policy directly, acting on the dependent variable only through the possible endogenous variable, which is leverage (being exogenous). For simplicity we used the total Debt to Capital, instead of dividing it between short and long term, to facilitate the implementation of the instrument.

The main idea of the test is to first estimate a reduced equation, which is similar to the structural equation (the equation we want to estimate initially, in our case, the model for cash holdings), but the dependent variable in this reduced equation is the possible endogenous variable (leverage), the main independent variable is the instrument (Sector Average Debt), and the controlling variables are the other regressors of the structural equation. The reduced equation is shown below:

$$
\begin{aligned}
& D / C a p_{i t}=\alpha_{i}+\beta_{1} \text { AvgSectorDebt }{ }_{i t}+\beta_{2} \text { sqrtMVE }_{i t} \\
& +\beta_{3} \text { NetCapex } / T A_{i t}+\beta_{4} P P E / T A_{i t} \\
& +\beta_{5} S G A / N O R_{i t}+\beta_{6} N O R / T A_{i t} \\
& +\beta_{7} \text { Beta }_{i t}+\beta_{8} \text { Div. Yld }_{i t}+\beta_{9} \text { Constr.Firms }_{i t}+\varepsilon_{i t}
\end{aligned}
$$

One important condition is that the coefficient for the instrument must be statistically different from zero to ensure relevance (in our model, coefficient betal for AvgSectorDebt). After estimating the reduced equation, the residual of this regression is to be included as a regressor in the structural equation, and in the case that the residual of the reduced equation is correlated with the residual of the structural equation (being a significant regressor in the structural equation regression), indeed the hypothesis of endogeneity holds. The residual of the structural equation becomes a function of the residual of the reduced equation (Vit) plus an error term (Nit).

$$
\varepsilon_{i t}=\gamma_{1} v_{i t}+\eta_{i t}
$$

Finally, we replace the residual epsilon, as defined above, in the structural equation:

$$
\begin{aligned}
C / T A_{i t}= & \beta_{1} D / \text { Cap }_{i t}+\beta_{2} \text { sqrtMVE }_{i t}+\beta_{3} \text { NetCapexAssets }_{i t} \\
& +\beta_{4} \text { PPE } / \text { TA }_{i t}+\beta_{5} S G A / \text { NOR R }_{i t}+\beta_{6} \text { NOR }_{\text {TI }} A_{i t} \\
& +\beta_{7} \text { Beta }_{i t}+\beta_{8} \text { DivYld }_{i t}+\beta_{9} \text { Constr }_{i t}+\gamma_{1} v_{i t}+\eta_{i t} \\
& \gamma_{1} \neq 0
\end{aligned}
$$

The main condition for the endogeneity to hold is that the coefficient Gamma1 must be statistically different from zero. We rejected this hypothesis, thus concluding for the model of cash holdings we specified that leverage is not endogenous (results are reported in the next section). This finding suggested that using separate equations would be more appropriate, as in the absence of endogeneity among variables, the Fixed Effects estimator is more efficient than the Instrumental Variables or Two-Stage Least squares estimators, as the Fixed Effects estimator applies OLS after the demeaning of variables (Wooldridge, 2004). 


\section{RESULTS}

4.1 Descriptive Statistics.

The Table 1 presents the main descriptive statistics for the variables analyzed in the study:

Table 1 Descriptive statistics for the sample - 2002/2012

\begin{tabular}{|c|c|c|c|c|c|c|}
\hline & Mean & St.Dev & $25 \%$ Perc. & Median & $75 \%$ Perc. & $\mathbf{N}$ \\
\hline Cash/Assets & 0.125 & 0.137 & 0.020 & 0.080 & 0.175 & 2346 \\
\hline Debt/Cap & 0.377 & 0.249 & 0.175 & 0.382 & 0.548 & 2358 \\
\hline ST Debt/Cap & 0.161 & 0.167 & 0.04 & 0.114 & 0.222 & 2357 \\
\hline LT Debt/Cap & 0.215 & 0.189 & 0.030 & 0.188 & 0.346 & 2358 \\
\hline AvgSectorDebt & 0.377 & 0.037 & 0.356 & 0.369 & 0.397 & 2358 \\
\hline $\operatorname{lnTA}$ & 13.9 & 2.0 & 12.7 & 14.0 & 15.2 & 2358 \\
\hline InNOR & 13.3 & 2.2 & 12.2 & 13.5 & 14.7 & 2262 \\
\hline sqrtMVE & 13.2 & 2.3 & 11.6 & 13.4 & 14.9 & 2358 \\
\hline ROIC & 0.138 & 0.288 & 0.040 & 0.080 & 0.149 & 2311 \\
\hline NOR/TA & 0.702 & 0.554 & 0.300 & 0.600 & 1.100 & 2357 \\
\hline MBK & 0.894 & 1.300 & 0.246 & 0.542 & 1.070 & 2348 \\
\hline FE/EBITDA & 0.356 & 0.256 & 0.157 & 0.298 & 0.532 & 1668 \\
\hline Liq & 0.332 & 2.270 & 0.002 & 0.102 & 0.238 & 2007 \\
\hline PРE/TA & 0.317 & 0.241 & 0.09 & 0.301 & 0.487 & 2358 \\
\hline SGA/NOR & 0.254 & 1.29 & 0.108 & 0.164 & 0.253 & 2147 \\
\hline Beta & 0.799 & 0.674 & 0.30 & 0.60 & 1.1 & 1299 \\
\hline Div. Yield (\%) & 2.95 & 4.50 & 0 & 1.30 & 4.10 & 1748 \\
\hline Constr & 0.460 & 0.498 & 0 & 0 & 1 & 2358 \\
\hline $\mathrm{EB} / \mathrm{TA}$ & 0.129 & 0.103 & 0.06 & 0.109 & 0.173 & 2229 \\
\hline NetCapex/TA & 0.04 & 0.08 & 0 & 0.02 & 0.05 & 2191 \\
\hline
\end{tabular}

In the analysis of descriptive statistics we focus on cash holdings and debt levels, as they are the main variables of interest of the study. Average Cash to Assets ratio was $12.5 \%$ of cash over total assets. Firms in the lowest $25 \%$ percentile had on average only $2 \%$ of cash out of total assets. Median cash holdings was $8 \%$ of cash out of total assets, whereas firms in the $75 \%$ percentile had cash positions of over $17 \%$ of cash out of total assets. Comparing these numbers with prior studies, Opler et al. (1999) reported that the average cash-to-assets ratio (assets net of cash) for their sample of US publicly traded firms was $17 \%$, with median of $6 \%$. Ozkan and Ozkan (2004) reported a cash-to-assets ratio of $10 \%$ for publicly traded UK firms. Bigelli and Sanchez-Vidal (2012) found cash-to-assets ratio of $10 \%$ of privately held Italian firms. Ferreira and Vilela (2004) reported $14.8 \%$ of cash-to-assets ratio for European firms. We can notice that cash holdings of Brazilian firms are roughly in the same pattern, being slightly higher comparing the mean with the UK evidence and the median with the US evidence. Compared with European firms, cash holdings of Brazilian firms are roughly in the same proportion.

For Debt to Capital, the mean was $37 \%$ of debt out of total capital. Low debt firms in the $25 \%$ percentile had $17 \%$ of debt to total capital, whereas firms in the $75 \%$ percentile presented debt to capital ratios of over 55\%. Opler et al. (1999) reported $21 \%$ of debt to assets ratio, whereas Ferreira and Vilela (2004) documented 24\% for the same variable. For better comparison sake, Debt to Assets for Brazilian firms was 28\%, a figure close, but slightly higher than for US and for European firms. Long-term Debt was $21.5 \%$ of total capital, whereas Short-term debt was $16.1 \%$ of total capital employed.

\subsection{Results of Regressions.}

Table 2 Determinants of debt

\begin{tabular}{l|l|l|l}
\hline $\begin{array}{l}\text { Dep.Var: } \\
\text { Debt/Capital }\end{array}$ & Coefficients & t-value & Robust SE. \\
\hline C/TA & $-0.100^{*}$ & -1.67 & 0.059 \\
\hline InTA & $0.068^{* * *}$ & 5.28 & 0.013 \\
\hline NetCapex/TA & $0.088^{*}$ & 1.87 & 0.047 \\
\hline ROIC & -0.001 & -0.62 & 0.001 \\
\hline EBITDA/TA & 0.044 & 0.56 & 0.080 \\
\hline FE/EBITDA & $0.356^{* * *}$ & 4.19 & 0.085 \\
\hline (FE/EBITDA)sq & $-0.169^{*}$ & -1.96 & 0.086 \\
\hline Liq & 0.006 & 0.77 & 0.008 \\
\hline F(8,280) & $14.4^{* * *}$ & \\
\hline$N$ & 1574 & & \\
\hline Firms & 275 & & \\
\hline Adj. $R$-squared & 0.2113 & \\
\hline DWatson & 2.40 & 0.7581 & \\
\hline Var(u_i) & 0.57 &
\end{tabular}

*** Significant at 0.01 level; ** Significant at 0.05 level; *Significant at 0.1 level 
Table 2 summarizes results for Model 1. Debt to Capital ratio is the dependent variable, whereas Cash Holdings is the main independent variable in which we are interested. The regression is statistically significant, presenting an Adjusted R-squared of 0.2113. Cash Holdings, measured by Cash-to-Assets ratio is negatively related to leverage $(-0.10 ; \mathrm{p}$-value $<0.1)$. Firm size, measured by the natural $\log$ of assets, is positively related to leverage (0.06; $\mathrm{p}$-value $<0.01)$. Leverage is increasing in growth / investment opportunities, as measured by the NetCapex/TA (0.08; p-value < 0.1). Profitability (ROIC) and Gross Cash Flows to Total Assets (EB/TA) were not statistically different from zero. The relationship between Financial Expenses to EBITDA (FE/EBITDA) and leverage is not linear, as both the linear and quadratic forms of the variable are statistically significant (Linear form: 0.356 ; p-value < 0.01; Quadratic form: -0.169 ; $\mathrm{p}$-value < $0.1)$. Liquidity of stocks traded, measured by the variable Liq (volume traded divided by Market Value of Equity), is not statistically significant.

The finding that leverage is decreasing in cash holdings is in line with findings of other prior studies (Opler et al., 1999; Ferreira \& Vilela, 2004; Bigelli \& Sanchez-Vidal, 2012; D'Mello et al., 2008). Also, it makes sense in light of Pecking Order, as these sources of funds can be considered alternative resources one to the other, because firms holding more cash would use this cash reserves to finance projects, having a lower need for external financing and hence employing less debt (Sunder \& Myers, 1999).

Leverage as an increasing function of size is in line with former studies. Following Rajan and Zingales (1995), larger firms can use their assets base as a collateral, and borrow more money at lower relative costs, hence being able to use more debt financing. Debt being increasing in investments signals that firms are financing growth opportunities with debt rather than with internal resources.

The last discussion on the first model is about the relationship between debt and debt cost or gross cash flow commitment to pay the debt service (Financial Expenses over EBITDA). The econometric model supports an inverted Ushaped relationship between these two variables, or, in other words, there would be a given level of gross cash flow commitment to repay debt that would maximize the debt level, as the coefficient for the liner term of FE/EBITDA is positive and the coefficient for the quadratic term for the variable is negative, being both statistically significant. Further, from that given point, it could be the case that debt becomes too expensive and, at the margin, starts to decrease. This result is in synergy with the argument of D'Mello et al. (2008), that firms paying higher service on their debts are more likely to face financial distress, so debt levels are expected to fall at the margin as debt service cost rises.

This result, however, does not imply that firms over this maximum threshold are necessarily debt-constrained, as the result is derived from an average-median behavior. But the econometric result gives some intui- tion that firms that commit too much of their gross cash flow generation paying financial expenses are likely to become constrained if this commitment becomes too elevated. This was the intuition that led us to set firms only in the $75 \%$ percentile of FE/EBITDA, instead of using the mean or median as a threshold, as candidates for being financially constrained firms when we designed the dummy we used for the model of Cash Holdings and Firm Value.

The second model we estimated had Cash Holdings, measured by Cash-to-Assets ratio as dependent variable, and short and long-term debt to capital as the main independent variables. Before presenting the results of this model, we present the results for the test of endogeneity of leverage and cash holdings:

Table 3 Test of endogeneity (reduced equation)

\begin{tabular}{|c|c|c|c|}
\hline $\begin{array}{l}\text { Dep.Var: } \\
\text { DebtToCapital }\end{array}$ & Coefficients & $t$-value & Robust SE. \\
\hline SectorDebt & $0.584^{*}$ & 1.88 & 0.311 \\
\hline sqrtMVE & $-0.001^{* * *}$ & -3.34 & 0.001 \\
\hline NetCapex/TA & $0.140^{*}$ & 1.67 & 0.084 \\
\hline PPE/TA & $-0.148^{* * *}$ & -3.62 & 0.041 \\
\hline$S G A / N O R$ & $-0.027^{* *}$ & -2.17 & 0.012 \\
\hline NOR/TA & $-0.084^{* *}$ & -2.20 & 0.038 \\
\hline Beta & 0.005 & 0.68 & 0.008 \\
\hline Div.Yield & -0.006 & -0.46 & 0.001 \\
\hline Constr & $0.075^{* * *}$ & 4.27 & 0.017 \\
\hline$F(9,209)$ & $7.37^{* * *}$ & & \\
\hline N & 1103 & & \\
\hline Firms & 210 & & \\
\hline Adj. R-squared & 0.041 & & \\
\hline DWatson & 2.39 & & \\
\hline $\operatorname{Var}\left(u_{-} \_i\right)$ & 0.766 & & \\
\hline Max. correl. & -0.27 & & \\
\hline
\end{tabular}

*** Significant at 0.01 level; ${ }^{* *}$ Significant at 0.05 level; *Significant at 0.1 level

From the results of the reduced equation estimation, it can be seen that the instrument used, the Average Sector Debt, was indeed relevant, as its' coefficient is statistically different from zero. Next table brings the results for the structural equation, including the residual of the reduced equation (Vit) as a regressor: 
Table 4 Test of endogeneity (structural equation)

\begin{tabular}{l|l|l|l}
\hline $\begin{array}{l}\text { Dep.Var: } \\
\text { CashAssets }\end{array}$ & Coefficients & t-value & Robust SE. \\
\hline DebtToCapital & $-0.112^{* * *}$ & -2.78 & 0.045 \\
\hline sqrtMVE & -0.001 & -0.65 & 0.001 \\
\hline NetCapex/TA & -0.040 & -0.64 & 0.063 \\
\hline PPE/TA & $-0.118^{* *}$ & -2.19 & 0.056 \\
\hline SGA/NOR & $0.011^{* * *}$ & 12.80 & 0.001 \\
\hline NOR/TA & -0.035 & -1.33 & 0.028 \\
\hline Beta & 0.005 & 1.27 & 0.004 \\
\hline Div.Yield & 0.001 & 0.10 & 0.006 \\
\hline Constr & 0.007 & 0.27 & 0.027 \\
\hline Vit & 0.205 & 0.28 & 0.2920 \\
\hline F(10,208) & $108.64^{* * *}$ & & \\
\hline N & 1102 & & \\
\hline Firms & 209 & & \\
\hline Adj. R-squared & 0.087 & & \\
\hline DWatson & 2.29 & & \\
\hline Var(U_i) & 0.745 & & \\
\hline Max. correl. & 0.28 & & \\
\hline & & & \\
\hline & & & \\
\hline & & & \\
\hline
\end{tabular}

*** Significant at 0.01 level; ** Significant at 0.05 level; *Significant at 0.1 level

The regressor of interest in this regression is Vit, exactly the residual of the reduced equation. As the coefficient for this variable is not statistically different from zero, the conclusion is that leverage and cash holdings are not endogenous, according to the test specification presented in the previous section.

The next table brings the results for the regression that has cash holdings as dependent variable:

Table 5 Determinants of cash holdings

\begin{tabular}{l|c|c|c}
\hline $\begin{array}{l}\text { Dep.Var: } \\
\text { Cash Holdings }\end{array}$ & Coefficients & t-value & Robust SE. \\
\hline stD/Cap & $-0.128^{* * *}$ & -3.60 & 0.035 \\
\hline ItD/Cap & $-0.100^{* *}$ & -2.02 & 0.049 \\
\hline SqrtMVE & $-0.001^{*}$ & -1.75 & 0.000 \\
\hline NetCapex/TA & -0.030 & -0.68 & 0.045 \\
\hline PPE/TA & $-0.130^{* * *}$ & -4.30 & 0.030 \\
\hline SGA/NOR & $0.011^{* * *}$ & 22.9 & 0.000 \\
\hline NOR/TA & $-0.041^{* * *}$ & -3.44 & 0.012 \\
\hline Beta & 0.006 & 1.61 & 0.003 \\
\hline Div.Yield & 0.000 & 0.01 & 0.000 \\
\hline Constr.Firms & 0.013 & 1.07 & 0.012 \\
\hline
\end{tabular}

\begin{tabular}{l|l}
\multicolumn{2}{l}{ continued } \\
\hline$F(10,215)$ & $119.9^{* * *}$ \\
\hline$N$ & 1101 \\
\hline Firms & 209 \\
\hline Adj. R-squared & 0.091 \\
\hline DWatson & 2.27 \\
\hline Var(u_i) & 0.7448 \\
\hline Max. correl. & 0.36 \\
\hline
\end{tabular}

*** Significant at 0.01 level; ** Significant at 0.05 level; *Significant at 0.1 level

Short and long-term Debt to Capital had both a negative marginal effect on Cash Holdings (-0.12; p-value $<0.01 /-0.10$; p-value $<0.05$, respectively), being the negative effect of short-term debt more pronounced. The proxy for Size (sqrtMVE) was negatively correlated to Cash Holdings $(-0.001$; p-value $<0.1)$, but with a coefficient close to zero. Net Capex to Assets (NetCapex/TA), our proxy for Growth / Investment Opportunities was not statistically significant. Tangible Assets (PPE/TA) had negative effect on Cash Holdings (-0.13; p-value $<0.01$ ), whereas Discretionary Expenses (SGA/NOR) marginally increase Cash Holdings (0.01; p-value < 0.01). Asset Turns (NOR/TA), the variable for operating efficiency, had negative relationship to Cash Holdings $(-0.04 ;$ p-value $<0.01)$, while Beta, the proxy for firm risk, was not statistically different from zero, the same for the variables Dividend Yield and Constr (the dummy variable for potentially constrained firms).

The result that Cash Holdings is decreasing in debt is in line both with the previous result we found having Debt to Capital as dependent variable and Cash Holdings as independent variable, and also with prior studies. (Opler et al., 1999; Ferreira \& Vilela, 2004; Bigelli \& Sanchez-Vidal, 2012). Because we split the Debt to Capital ratio to encompass the debt maturity, we could assess if the maturity of debt magnifies or reduces the negative impact of debt into cash holdings. Results suggest that Short-Term Debt has a slightly more negative impact on Cash Holdings than Long-Term Debt (coefficients are $-0.12 \times-0.10$, respectively). If we assume that short-term debt is more likely to be used to finance immediate cash shortages, like for working capital necessities, and that long term debt is more likely to be used to finance investments, this result makes some sense, as cash holdings are liquid assets that firms can use in case of an immediate need to cover working capital shortage, as short-term debt, at least in Brazil, is quite expensive money. But as the difference in the coefficients is small, we leave this finding as possibility to be further developed.

According to the regression results, firms holding more tangible assets are likely to hold less cash, in line with John (1993). On the other hand, firms with more discretionary expenses, like advertising, research, selling expenses, etc, hold higher cash balances, which is in line with former studies (Opler et al., 1999). Regar- 
ding to Operating Efficiency / Performance, we found that Asset Turns and Cash Holdings are negatively correlated. Instead, previous studies suggested that firms holding larger cash balances usually are more efficient (Mikkelson \& Partch, 2003).

Cash Holdings is decreasing in Size, implying that smaller firms are likely to hold larger cash reserves, in synergy with former studies (Ferreira \& Vilela, 2004; Opler et al., 1999; D’Mello et al., 2008).

The dummy variable we used to capture financially constrained firms showed positive coefficient, suggesting cash holdings would be increasing in financial constraints. Unfortunately, because the coefficient is not statistically significant, we cannot corroborate this important result of prior research (as in Acharya et al., 2007; Almeida \& Campello, 2007).

However, it is possible that we captured some part of the idea of financially constrained firms with other variable in the model, which is size. It is reasonable to assume that smaller firms are likely to suffer more from financial constraints, as they do not have valuable assets to offer as a collateral to back the debt service, and may run out of cheap debt loans. This is especially pronounced in Brazil, building on Terra (2003). Thus, as the model supports that cash holdings is decreasing in size, and assuming that financially constrained firms are likely to be smaller, the model may have indirectly captured some of the positive relationship between financial constraint and cash holdings, as suggested by Acharya et al. (2007), D’Mello et al. (2008), among others.

\begin{tabular}{|c|c|c|c|}
\hline & Table 6 & Firm value & \\
\hline $\begin{array}{l}\text { Dep.Var: } \\
\text { Mkt-to-Book }\end{array}$ & Coefficients & t-value & Robust SE. \\
\hline$s t D / C a p$ & $-0.707^{* *}$ & -2.24 & 0.316 \\
\hline ItD/Cap & $-0.953^{* * *}$ & -2.93 & 0.325 \\
\hline$C / T A$ & $2.466^{* * *}$ & 3.54 & 0.695 \\
\hline$(C / T A) s q$ & $-2.620^{* *}$ & -2.14 & 1.222 \\
\hline Constr & $-0.153^{* * *}$ & -3.33 & 0.046 \\
\hline NetCapex/TA & 0.391 & 1.27 & 0.300 \\
\hline $\ln N O R$ & 0.062 & 1.22 & 0.050 \\
\hline Liq & $-0.132^{* * *}$ & -3.35 & 0.039 \\
\hline ROIC & $0.018^{* *}$ & 2.01 & 0.009 \\
\hline stDebtxConstr & 0.010 & 0.04 & 0.292 \\
\hline ItDebtxConstr & 0.002 & 0.02 & 0.156 \\
\hline CashxConstr & -0.502 & -1.43 & 0.352 \\
\hline$F(12,287)$ & \multicolumn{3}{|l|}{$7.49^{* * *}$} \\
\hline N & \multicolumn{3}{|l|}{2038} \\
\hline Firms & \multicolumn{3}{|l|}{288} \\
\hline Adj. R-squared & \multicolumn{3}{|l|}{0.1575} \\
\hline DWatson & \multicolumn{3}{|l|}{2.02} \\
\hline $\operatorname{Var}\left(u_{-} i\right)^{\prime}$ & \multicolumn{3}{|l|}{0.6878} \\
\hline Max. correl. & \multicolumn{3}{|l|}{0.35} \\
\hline
\end{tabular}

*** Significant at 0.01 level; ** Significant at 0.05 level; *Significant at 0.1 level
Table 6 reports the results for the third model estimated. Recalling, the idea of this model was to evaluate how investors perceive financing and cash policies, by assessing the impact of these policies on the firm value.

The Market-to-Book ratio is decreasing in ShortTerm Debt to Capital $(-0.70$; p-value $<0.05)$ and in Long-Term Debt to Capital $(-0.95$; p-value $<0.01)$. For Cash Holdings, the relationship is positive for the linear form (2.46; p-value $<0.01)$, but decreasing for the quadratic form $(-2.62$; p-value $<0.05)$. Constrained Firms have their market value further discounted by investors when compared to unconstrained firms $(-0.15$; $\mathrm{p}$ value $<0.01)$. The controlling variables for profitability (ROIC) and for liquidity (Liq) were statistically significant in the regression. The controls for size (log of Net Operating Revenues), investment (NetCapex/TA), as well as the interactions between short and long-term debt and cash holdings with the dummy for constrained firms were not statistically significant.

The result that both short and long-term debt causes marginal discounting in the market value of firms may reflect some kind of risk aversion of investors, trying to interpret that as an averaged behavior, as higher leverage tends to be associated with higher stock volatility (Lewellen, 2006). Indeed, as the Brazilian stock market is marked by high volatility (Perez \& Famá, 2006), one possibility is that investors would prefer firms to finance their investments with other securities than debt, like equity or internally generated funds, to mitigate the already present problem of volatility, making returns more stable. As firms, instead, must employ at least some level of debt in their financing structure, the negative marginal effect of debt into market value could be possibly interpreted as a risk-aversion reply from investors.

The fact that long-term debt caused a stronger discount on the market performance, when compared to short-term debt, was unexpected, because short-term interest rates are usually higher. One alternative explanation could be that, although short-term credit is more expensive, because it is due in a shorter period, the risk stemming from this debt can be better assessed by investors, because it is due in a shorter maturity, and investors can foresee more easily possible problems with this outstanding debt in the short term. On the other hand, because the state of the economy is more uncertain in the long run, maybe the risk of debt due in longer periods is harder to be assessed, causing investors to further discount the market value of firms with long-term leverage. A negative relationship between higher levels of debt and stock market returns or market value of equity is in line with the findings of Dimitrov and Jain (2008), who reported that growing debt is associated to negative stock market returns. However, Masulis (1983) reported opposite results when studying US listed firms, as he found that changes in leverage were positively related to both stock returns and to firm value. 
Firm value was found to be increasing in the linear form of Cash Holdings, but decreasing in the quadratic form, suggesting an inverted U-shaped curve relationship. Prior evidence suggested that cash holdings are valueenhancing if cash balances are optimal (Ferreira \& Vilela, 2004; Opler et al., 1999). In other words, static trade-off theory predicts that there is a target-level of cash holdings that maximizes firm value. The results of the model give support to static trade-off theory, in the sense that it supports the existence of an optimum value of cash. Firm value would be increasing in cash up to a given threshold value, but, from that point, value would start to be discounted. Investors may value the precautionary feature of high cash balances, as argued by Bates et al. (2009), but not in a monotonic way, as excess cash balances may signal high opportunity costs of funds, or also an inefficient payout policy, because holding cash may have non-zero cost, and some part of the excess cash could be distributed as dividends (Opler et al., 1999). One further reason for the discount on higher values of cash could be linked to the agency problem of leaving too much cash in the managers' hand, as they could invest in low-profit projects and spend the excess cash in perquisites (Jensen, 1986).
In the Brazilian context, we understand that an optimum point of cash makes sense, because there is a marked restriction in credit markets, specially for small firms, but also a high opportunity cost of capital, as interest rates are historically higher when compared to more developed economies. Then too little cash can be viewed as a bad thing, but also too much cash may not be the best option, suggesting there should be a balance point.

The dummy variable we set to differentiate potentially constrained firms versus unconstrained firms showed to be statistically significant and had negative coefficient. Interpretation is that constrained firms have lower market value, when compared to the baseline-unconstrained firm. This result is consistent with the hypothesis of risk aversion that we proposed for the negative impact of debt in the market value, as firms paying a high fraction of their gross cash generated in debt servicing may be more prone to face financial distress, thus being riskier, and hence suffering further discounting. The interaction between this dummy and short and long-term debt, as well as the interaction with cash holdings, were not statistically significant.

\section{CONCLUSIONS, LIMITATIONS AND FURTHER RESEARCH}

The objective of this study was to analyze how capital structure and cash holdings are related in the Brazilian firms setting, and further evaluate the impact of these important financial variables on the firm value. We found evidence that leverage and cash holdings are negatively related at the margin. Higher levels of cash balances are associated to less leverage, and more levered firms are likely to hold less cash. The finding was in line with former researches, and can also be interpreted in light of Pecking Order theory, as firms would prefer to finance investments with retained earnings (encompassed by cash holdings), recurring to debt as a second option to finance investments when they run short of cash. Hence, it makes sense those higher levels of cash to be associated to lower debt ratios, and vice-versa.

We also found evidence that higher levels of leverage end up constraining firms to issue more debt, as the gross cash generated that is committed to repay debt, once it reaches a given threshold, causes debt to fall at the margin. If we consider that small firms are more likely to be financially constrained, as former research and theory suggest, we found indirect evidence that more constrained firms hold more cash.

Regarding to the impact of leverage (short and longterm) and cash holdings on firm value, the results of this study suggest that leverage causes firm value discounts, whereas cash balances are valued positively by investors, but up to a certain level. Further from that given level, the market value of firm is decreasing in cash holdings. Additionally, the firms we set as financially constrained were further discounted in their market values, when compared to the ones set as unconstrained.

We interpreted these results as signaling a somewhat risk-averse behavior of investors with respect to leverage, because leverage could induce an even higher volatility to stock returns, and financially constrained firms are more subject to financial distress risks. Regarding to cash holdings, the results suggest that the accumulation of cash balances is positive, as it potentially shields the firm's future investments against possible future cash constraints, but not in a monotonic fashion: too much cash causes market discounts, possibly due to escalated opportunity costs of money, inefficient payout policy or agency costs of leaving too much cash disposable to managers' spending.

We point out that our study has some important limitations. First, we addressed the issue of financially constrained firms using a different approach when compared to prior studies, mainly due to data availability. The dummy variable we used may not have substantially captured the capital constraint faced by firms, despite the fact that we understand that the dummy captured some features of the problem, and some other features were indirectly captured by other variable (size). Second, also related to financial constraints, we failed to conciliate it with sensitivity to cash flows, investment and tangibility, in light of prior studies (Acharya et al, 2007; Almeida \& Campello, 2007). These more robust relationships should be addressed in future studies. Another variable that we failed to conciliate in our study is the role of taxes in both cash holdings and leverage determinants. Further papers should include this variable in the analysis.

Finally, we estimated three separate models for leverage, cash holdings and firm value, based on our understanding 
of what the current theory could support. Our interpretation was that simultaneous equations were not the best choice, especially to model firm value, cash holdings and leverage. For the relationship between cash holdings and leverage, we provided evidence that variables were not endogenous, at least for our model specification. Thus, we opted for estimating separate regressions.

However, clearly, these are matters of interpretation, and further studies could and should try to explore other specifications, provided the theoretical base to do so is well developed.
We acknowledge that modeling the three variables separately can be considered a limitation, but by not building on more complicated assumptions that we found no strong support in the theory, we understand that we stood on the safe side. The models we estimated can be considered simple, but our view is that they were correctly specified and yielded interesting results, specially when considering that there were not so many studies before that attempted to study these three variables altogether. But for sure the models suggested in this study leave room for more robust specifications.

\section{References}

Acharya, V., Almeida, H., \& Campello, M. (2007). Is cash negative debt? A hedging perspective on corporate financial policies. Journal of Financial Intermediation, 16 (4), 515-554.

Adrian, T., \& Shin, H. S. (2010). Liquidity and leverage. Journal of Financial Intermediation, 19 (3), 418-437.

Almeida, H., \& Campello, M. (2007). Financial constraints, asset tangibility, and corporate investment. Review of Financial Studies, 20 (5), 1429-1460.

Amihud, Y. (2002 January). Illiquidity and stock returns: cross-section and time-series effects. Journal of Financial Markets, 5 (1), Issue 1,31-56.

Bancel, F., \& Mittoo, U. R. (2004 Winter). Cross-country determinants of capital structure choice: a survey of European firms. Financial Management, 33 (4), 103-132.

Bates, T. W., Kahle, K. M., \& Stulz, R. (2009 October). Why do U.S. firms hold so much more cash than they used to? Journal of Finance, 64 (5), 1985-2021.

Bigelli, M., \& Sánchez-Vidal, J. (2012). Cash holdings in private firms. Journal of Banking \& Finance, 36 (1), 26-35.

Bradley, M., Jarrel, A. G., \& Kim, E. H. (1984 July). On the existence of an optimal capital structure: theory and evidence. Journal of Finance, 39 (3), 857-878.

Denis, D. J., \& Sibilkov, V. (2010). Financial constraints, investment, and the value of cash holdings. Review of Financial Studies, 23 (1), 247-269.

Dimitrov, V., \& Jain, P. (2008). The value-relevance of changes in financial leverage beyond growth in assets and GAAP earnings. Journal of Accounting, Auditing \& Finance, 23 (2), 191-222.

Dittmar, A., \& Mahrt-Smith, J. (2007). Corporate governance and the value of cash holdings. Journal of Financial Economics, 83 (3), 599-634.

D’Mello, R., Krishnaswami, S., \& Larkin, P. (2008). Determinants of corporate cash holdings: evidence from spin-offs. Journal of Banking \& Finance, 32 (7), 1209-1220.

Ferreira, M. A., \& Vilela, A. S. (2004). Why do firms hold cash? Evidence from EMU countries. European Financial Management, 10 (2), 295-319.

Frank, M. Z., \& Goyal, V. K. (2009 Spring). Capital structure decisions: which factors are reliably important? Financial Management, 38 (1), 1-37.

Fresard, L. (2010). Financial strength and product market behavior: the real effects of corporate cash holdings. The Journal of Finance, 65 (3), 1097-1122.

Futema, M. S., Basso, L. F. C., \& Kayo, E. K. (2009). Estrutura de capital, dividendos e juros sobre o capital próprio: testes no Brasil. Revista Contabilidade \& Finanças, São Paulo, 20 (49), 44-62.

Gujarati, N. D. (2006). Econometria básica. (4. ed.). Rio de Janeiro: Elsevier.

Han, S., \& Qiu, J. (2007). Corporate precautionary cash holdings. Journal of Corporate Finance, 13 (1), 43-57.

Harris, M., \& Raviv, A. (1991). The theory of optimal capital structure. Journal of Finance, 46 (1), 297-356.

Hovakimian, A., Opler, T., \& Titman, S. (2001 March). The debt-equity choice. Journal of Financial and Quantitative Analysis, 36 (1), 1-24.

Jensen, M. (1986). Agency costs of free cash flow, corporate finance, and takeovers: American Economic Review, 76 (2), 323-29.

John, T. A. (1993). Accounting measures of corporate liquidity, leverage, and costs of financial distress. Financial Management, 22 (3), 91-100.

Kayhan, A., \& Titman, S. (2007 January). Firms' histories and their capital structures. Journal of Financial Economics, 83 (1), 1-32.

Kayo, E. K., \& Famá, R. (1997). Teoria de agência e crescimento: evidências empíricas dos efeitos positivos e negativos do endividamento. Cadernos de Pesquisa em Administração, 2 (5), 1-8.

Kayo, E. K., Teh, C. C., \& Basso, L. M. C. (2006 Abril-Junho). Ativos intangíveis e estrutura de capital: a influência das marcas e patentes sobre o endividamento. Revista de Administração - RAUSP, 41 (2), 158-168.

Leland, H. E. (1998 August). Agency costs, risk management and capital structure. Journal of Finance, 53 (4), 1213-1243.
Lewellen, K. (2006). Financing decisions when managers are risk averse. Journal of Financial Economics, 82 (3), 551-589.

Lipson, M., \& Mortal, S. (2009 November). Liquidity and capital structure. Journal of Financial Markets, 12 (4), 611-644.

Masulis, R. (1983). The impact of capital structure change on firm value: Some estimates. The Journal of Finance, 38 (1), 107-126.

Mikkelson, W., \& Partch, M. (2003). Do persistent large cash reserves hinder performance? Journal of Financial and Quantitative Analysis, 38 (2), 275-294.

Miller, M., \& Orr, D. (1966). A model of the demand of money by firms. Quarterly Journal of Economics, 80 (3), 413-435.

Modigliani, F., \& Miller, M. H. (1958 June). The cost of capital, corporate finance and the theory of investment. American Economic Review, 48 (3), 261-297.

Morellec, E. (2001 August). Asset liquidity, capital structure and secured debt. Journal of Financial Economics, 61 (2), Issue 2, 173-206.

Myers, S. C. (1984 July). The capital structure puzzle. Journal of Finance, 39 (3), 575-592.

Myers, S. C., \& Majluf, N. S. (1984). Corporate financing and investment decisions when firms have information that investors do not have. Journal of Financial Economics, 13 (2), 187-222.

Neumeyer, P., \& Perri, F. (2005). Business cycles in emerging economies: the role of interest rates. Journal of monetary Economics, 52 (2), 345-380.

Opler, T., Pinkowitz, L., Stulz, R., \& Williamson, R. (1999). The determinants and implications of corporate cash holdings. Journal of Financial Economics, 52 (1), 3-46.

Ozkan, A., \& Ozkan, N. (2004). Corporate cash holdings: an empirical investigation of UK companies. Journal of Banking \& Finance, 28 (9), 2103-2134.

Perez, M., \& Famá, R. (2006). Ativos intangíveis e o desempenho empresarial. Revista Contabilidade \& Finanças, 17 (40), 7-24.

Perobelli, F. F. C., \& Famá, R. (2003). Fatores determinantes da estrutura de capital para empresas latino-americanas. Revista de Administração Contemporânea, 7 (1), 09-35.

Portal, M. T., Zani, J., \& da Silva, C. E. S. (2012 Janeiro-Abril). Financial frictions and substitution between internal and external funds in publicly traded Brazilian companies. Revista Contabilidade \& Finanças, 23 (58), 19-32.

Procianoy, J. L., \& Schmitt, F. O. V. (1995). O pacote fiscal de 1995: estratégias que otimizam os recursos dos investidores. Revista de Administração de Empresas, 35 (5), 46-58.

Rajan, R. G., \& Zingales, L. (1995 December). What do we know about capital structure? Some evidence from international data. Journal of Finance, 50 (5), 1421-1460.

Ross, S. A. (1977). The determination of financial structure: the incentive signaling approach. Bell Journal of Economics, 8 (1), 23-40.

Sheng, H., \& Saito, R. (2008). Liquidez das debêntures no mercado brasileiro. Revista de Administração da Universidade de São Paulo (RAUSP), 43 (2), 176-185.

Sunder, L., \& Myers, S. (1999). Testing static tradeoff against pecking order models of capital structure. Journal of Financial Economics, 51 (2), 219-244.

Smart, S. B., Megginson, W. L., \& Gitman, L. J. (2007). Corporate finance. USA: Thomson South-Western.

Terra, M. C. T. (2003 Abril-Junho). Credit constraints in Brazilian firms: evidence from panel data. Revista Brasileira de Economia, 57 (2), 443-464.

Titman, S., \& Wessels, R. (1988). The determinants of capital structure choice. Journal of Finance, 43 (1), 1-19.

Wooldridge, J. M. (2004). Introductory econometrics: a modern approach. (2. ed.). Ohio: South-Western College Pub. 